\title{
PERBAIKAN METODE IDENTIFIKASI POTENSI PENGEMBANGAN LAHAN UNTUK TAMBAK AIR PAYAU SISTEM EKSTENSIF LEWAT INTEGRASI LOGIKA SAMAR DAN PENGINDERAAN JAUH
}

\author{
Tarunamulia*), Jesmond Sammut"*), dan Akhmad Mustafa") \\ *) Balai Riset Perikanan Budidaya Air Payau, Maros \\ Jl. Makmur Dg. Sitakka, Maros, Sulawesi Selatan 90511 \\ E-mail:tarunamulia@yahoo.com \\ ${ }^{* *}$ The University of New South Wales, Sydney-Australia
}

(Naskah diterima: 4 Agustus 2009; Disetujui publikasi: 25 Januari 2010)

\begin{abstract}
ABSTRAK
Tersedianya data potensi lahan tambak yang cepat, akurat dan lengkap untuk kebutuhan pengelolaan kawasan pengembangan perikanan budidaya air payau harus didukung oleh metode identifikasi yang efektif dan efisien. Penelitian ini bertujuan untuk mengupayakan peningkatan kualitas metode klasifikasi multispektral dalam penginderaan jauh dalam mengidentifikasi potensi lahan tambak ekstensif dengan mengintegrasikan logika samar dalam proses klasifikasi citra. Citra landsat-7 ETM+ (30 $\mathrm{m}$ ), data elevasi digital dan data pengecekan lapang untuk wilayah pantai (kawasan tambak ekstensif/tradisional) Kecamatan Kembang Tanjung, Pidie, Nangroe Aceh Darussalam (NAD) digunakan sebagai bahan utama dalam penelitian ini. Klasifikasi multispektral standar secara terbimbing diperbaiki melalui pengambilan data training secara cermat, yang diikuti dengan uji keterpisahan objek, pemrosesan pascaklasifikasi dan analisis tingkat ketelitian. Hasil klasifikasi dengan tingkat ketelitian terbaik dari berbagai algoritma yang diujikan untuk tiga saluran selanjutnya dibandingkan dengan hasil klasifikasi dengan menggunakan logika samar. Dari hasil penelitian diketahui bahwa klasifikasi multispektral standar dengan algoritma Maximum Likelihood mampu menghasilkan informasi penutup lahan yang cukup lengkap dan rinci pada wilayah pertambakan dengan ketelitian yang cukup baik (>86\%). Tingkat ketelitian yang sama juga masih dijumpai walaupun hanya melibatkan kombinasi 3 saluran terbaik $(5,4$, dan 3$)$ yang dipilih berdasarkan analisis statistik nilai kecerahan piksel. Dengan membandingkan hasil terbaik dari metode klasifikasi standar yang berbasis logika biner (boolean) dengan hasil klasifikasi citra dengan logika samar dalam pengklasifikasian wilayah tambak, diketahui bahwa klasifikasi citra dengan logika samar mampu memperlihatkan hasil klasifikasi yang sangat baik untuk menentukan batas wilayah tambak yang tidak bisa dilakukan secara langsung bahkan oleh metode standar dengan algoritma terbaik. Dan dengan penambahan satu variabel kunci untuk tambak ekstensif seperti elevasi dalam klasifikasi, klasifikasi dengan logika samar dapat digunakan untuk memprediksi potensi pengembangan lahan budidaya tambak ekstensif dan kemungkinan tumpang tindih dengan penggunaan lahan lainnya.
\end{abstract}

KATA KUNCl: tambak, inderaja, logika samar

ABSTRACT: Improvement of methods to identify potential area for the development of extensive brackishwater ponds through the integration of fuzzy logic and remote sensing. By: Tarunamulia, Jesmond Sammut, and Akhmad Mustafa 
The availability of immediate, accurate and complete data on potential pond area as a baseline data for land management of brackishwater aquaculture must be supported by effective and efficient identification methods. The objective of this study was to explore the possibility of improving the quality of multispectral image classification methods in identifying potential areas for extensive brackishwater aquaculture through the integration of fuzzy logic and classification of remotely sensed data. 2002 Landsat-7 Enhanced Thematic Mapper Data (30-m pixels), digital elevation data, and groundtruthing of training data (region of interest/ROI) of Kembang Tanjung coastal areas (Pidie, NAD) were used as the primary data in this study. Standard supervised multispectral classification methods were enhanced by collecting appropriate and unbiased training data, applying separability measures of ROI pairs, employing post-classification analysis, and assessing the accuracy of classification results. Different types of standard supervised classification algorithms were evaluated and a classification output with the highest accuracy was selected to be compared with the result from fuzzy logic classification. The study showed that a supervised classification method based on maximum likelihood analysis produced the best classification output of land use-cover over the coastal region (overall accuracy $>86 \%$ ). The accuracy remained at the same level although it involved only the best composite of 3 bands $(5,4$, and 3 ) determined by a rigorous statistical analysis of brightness values of pixels. It was clear that the fuzzy-based classification method was more effective in identifying potential extensive brackishwater pond areas compared to the best standard image classification based on binary logic (maximum likelihood). Also, by integrating elevation data as another key variable to determine the suitability of land for extensive brackishwater aquaculture, the fuzzy classification can be used to more accurately predict potential area suited for brackishwater aquaculture ponds and any possible overlapping activity with other land uses.

\section{KEYWORDS: brackishwater aquaculture, remote sensing, fuzzy logic}

\section{PENDAHULUAN}

Salah satu program kebijakan revitalisasi perikanan budidaya di Indonesia khususnya pada budidaya air payau adalah pengembangan penerapan manajemen kawasan (DKP, 2005). Untuk mengelola kawasan pantai dengan baik dibutuhkan data potensi lahan, baik yang sudah dimanfaatkan (existing) ataupun yang belum dimanfaatkan (potential). Jika data tersebut tersedia maka evaluasi tingkat pemanfaatan yang meliputi permasalahan, hambatan, dan peluang dapat diterapkan (DKP, 2003). Namun demikian hingga saat ini disadari bahwa data mengenai potensi lahan tersebut belum tersedia secara maksimal, hal ini dapat dilihat dari besarnya variasi estimasi luasan tambak dari instansiinstansi dalam lingkup pemerintah maupun yang tersedia pada lembaga-lembaga swadaya masyarakat. Data tersebut juga umumnya hanya berupa angka dari hasil sensus, bukan data spasial (keruangan) sehingga menyulitkan dalam interpretasi. Dari fakta di lapangan juga diketahui bahwa usaha budidaya air payau masih banyak yang tumpang tindih dengan kegiatan penggunaan lahan lainnya. Hal demikian juga merupakan indikator dari rendahnya kualitas data potensi lahan.

Teknologi penginderaan jauh dan sistem informasi geografis (SIG) yang berfungsi mendukung tersedianya data tersebut masih mengalami berbagai macam kendala. Kendala utama antara lain persyarat teknis (perangkat keras dan perangkat lunak), biaya, ketersediaan dan kualitas data, dan pengembangan model (Burrough, 1998). Di Indonesia, citra satelit beresolusi spasial tinggi seperti IKONOS dan QuickBird belum tersedia secara luas, kalaupun ada, butuh dana yang besar untuk pengadaannya. Citra satelit seperti landsat-7 enhanced thematic mapper plus $\left(\mathrm{ETM}^{+}\right)$meskipun tersedia secara murah namun masih dianggap kurang mampu memberikan tingkat akurasi yang memadai sehubungan resolusi spasial dan kondisi ini diperparah dengan kemampuan perangkat lunak (softwares) dalam menurunkan informasi juga penuh dengan keterbatasan.

Jika dicermati secara seksama dari segi tujuan pemanfaatan dan lingkungan aplikasi, kegiatan perencanaan daerah termasuk manajemen kawasan pertambakan tidak mesti 
harus menunggu data dengan resolusi spasial tinggi. Citra landsat-7 ETM+ ${ }^{+}$yang memiliki 6 saluran (1-5 dan7) dengan resolusi spasial yang rata-rata $30 \mathrm{~m}, 1$ saluran (ETM6) dengan resolusi spasial $60 \mathrm{~m}$ ditambah 1 saluran pankromatik yang beresolusi spasial $15 \mathrm{~m}$ bisa dimanfaatkan untuk penyediaan data secara cepat dengan wilayah yang luas dan untuk peningkatan kualitas data yang ada.

Ketidakpuasan akan hasil analisis/ klasifikasi citra yang senantiasa diikuti dengan kesalahan (bias/galat) juga masih menjadi kendala dalam aplikasi. Bias yang susah dihindari dalam aplikasi perangkat lunak standar berbasis biner (binary/boolean) terdiri atas dua kategori yakni; bias memasukkan (an error of inclusion /commission error) dan bias mengeluarkan (an error of exclusion /omission error) (Falzarano \& Thomas, 2004; Jensen, 2005). Bias memasukkan adalah kesalahan yang terjadi akibat suatu area dimasukkan ke dalam kategori yang bukan miliknya sedangkan bias mengeluarkan terjadi akibat suatu area dikeluarkan dari kategori yang semestinya memang miliknya. Hal ini terjadi karena pada logika biner dasar pengambilan keputusan hanya dibatasi pada dua pilihan "ya" atau "tidak" (anggota atau bukan anggota) (Kusumadewi, 2002). Pada kenyataannya batas yang tegas/jelas antara penutup-penutup lahan sangat jarang dijumpai secara alami akan tetapi yang lebih umum adalah terjadinya gradasi dari suatu penutup lahan ke penutup lahan lainnya, sehingga dibutuhkan pendekatan lain yang mampu mengakomodasi kebingungan ketika satu area bisa dilabel dengan dua atau lebih kategori.

Pada perkembangan terakhir, selain metode klasifikasi multispektral klasik yang berbasis logika biner telah berkembang juga model klasifikasi dengan pendekatan logika samar (fuzzy logic). Logika samar ini telah dikembangkan sejak tahun 1965 dalam bentuk himpunan fuzzy (fuzzy sets), namun demikian istilah Logika samar (fuzzy logic) baru secara formal diperkenalkan oleh Professor Lotfi A. Zadeh dari Universitas California, Berkeley, Amerika Serikat pada tahun 1973. Berbeda dengan logika klasik dengan sifat tegas (crisp) yang menjelaskan nilai keanggotaan suatu item $x$ dalam himpunan $A\left(m_{A}[x]\right)$ yang hanya memiliki dua kemungkinan nilai yakni; 1 jika menjadi anggota dalam himpunan atau 0 jika tidak menjadi anggota dalam himpunan, maka logika samar ini memiliki derajat keanggotaan yang bernilai kontinu antara 0 sampai 1 (Kasabov, 1996; Chak \& Feng, 1998). Dengan demikian logika samar dimungkinkan pengkuantifikasian kekaburan dalam bentuk derajat keanggotaan (degree of membership) (Gopal \& Woodcock, 1994). Logika samar juga dapat membantu menyelesaikan ketidakjelasan bagi suatu tutupan lahan yang memiliki kelas keanggotaan yang tumpang tindih (overlapping class membership) dan memberikan petunjuk tentang tipe-tipe bias yang dihasilkan (Falzarano \& Thomas, 2004).

Dari uraian tersebut di atas nampaknya masih ada peluang dalam penyediaan data potensi lahan tambak secara cepat dengan memanfaatkan data yang tersedia secara murah seperti citra landsat-7 ETM ${ }^{+}$. Peluang tersebut masih bisa diupayakan dengan perbaikan metode standar yang berbasis logika biner dengan pengontrolan ketat pada proses klasifikasi mengingat metode ini sudah lebih dikenal dan digunakan secara luas serta dengan menggunakan pendekatan logika samar pada kasus-kasus yang membutuhkan informasi distribusi kesalahan. Penelitian ini bertujuan untuk mengupayakan peningkatan kualitas metode klasifikasi multispektral dalam penginderaan jauh dalam mengidentifikasi potensi lahan tambak ekstensif dengan mengintegrasikan logika samar dalam proses klasifikasi citra.

\section{BAHAN DAN METODE}

\section{Lokasi Penelitian dan Metode Verifikasi Lapang}

Penelitian ini dilaksanakan di wilayah pantai Kecamatan Kembang Tanjung Kabupaten Pidie, Provinsi Nangroe Aceh Darussalam (NAD) pada bulan Juni 2006. Daerah ini merupakan salah satu dari beberapa daerah pertambakan yang terkena dampak tsunami pada bulan Desember 2004. Pengecekan lapang dilakukan dengan metode sampling acak bertingkat (stratified random sampling), di mana dilakukan pengumpulan data latihan (training data) pada berbagai jenis penutup lahan dan bentuk lahan (terutama pada wilayah tambak) yang menempati suatu kelas yang telah diidentifikasi lewat analisis pendahuluan dengan memanfaatkan hasil klasifikasi tidak terbimbing (unsupervised classification) pada citra landsat-7 $\mathrm{ETM}^{+}$(enhanced thematic mapper Plus). Tiap kelas spektral yang dikunjungi dicatat koordinatnya dengan GPS receiver dan 
data tersebut disimpan sebagai data latihan untuk klasifikasi citra secara terbimbing dan sebagian lagi dipisahkan sebagai data penguji tingkat akurasi hasil klasifikasi.

\section{Analisis Citra Satelit Mengikuti Logika Biner (Boolean Logic) dengan Metode Terbimbing}

Pada citra multispektral resolusi sedang (landsat $\mathrm{ETM}^{+}, 30 \mathrm{~m}$ ) tahun 2000 yang terkoreksi geometrik dilakukan sampling piksel pada area yang diketahui secara pasti jenisnya di lapangan berdasarkan pemahaman konseptual mengenai pola respons spektral setiap jenis objek dalam ruang spektral (spectral space) (Jensen, 2005; Danoedoro, 2004). Untuk menunjang keakuratan pengambilan sampel pada setiap objek tersebut, digunakan berbagai data pendukung seperti peta rupa bumi dan citra satelit resolusi tinggi (ikonos) yang tersedia serta dengan memanfaatkan informasi lapang yang diketahui koordinatnya. Sampel-sampel piksel dengan jumlah total setiap area minimum 100 piksel disimpan dalam bentuk region of interest (ROI) dan pada setiap jenis objek diambil minimum 3 ROI.

Pada analisis multispektral ini hanya digunakan 7 saluran (band) utama dari 8 saluran yang tersedia yang meliputi saluran 1 , 2, 3, 4, 5, 7 dengan resolusi spasial 30 meter ditambah saluran 8 (pankromatik) dengan resolusi spasial 15 meter untuk mendapatkan ketelitian yang lebih tinggi. Sedangkan saluran ETM6 (inframerah termal) tidak digunakan dalam penelitian ini. Band 8 yang beresolusi tinggi ini dikomposit dengan saluran-saluran lainnya pada proses penajaman citra dengan metode Gram-Schmidt Spectral Sharpening. Sehingga didapatkan ketelitian spasial 15 meter.

Tahap kritis sebelum pelaksanaan proses klasifikasi multispektral dalam rangka peningkatan kualitas hasil klasifikasi adalah melakukan uji keterpisahan ROI (separability measures of ROIs). ROI yang diuji derajat keterpisahannya ini, merupakan ROI yang akan digunakan dalam proses klasifikasi (pemisahan objek), sedangkan ROI yang akan digunakan sebagai penguji disimpan secara terpisah. Tahapan ini bertujuan untuk mengetahui apakah spektral yang mewakili objek-objek tertentu dapat terpisah dengan baik. Tingkat keterpisahan itu dilihat dari nilai-nilai indeks separabilitas dalam bentuk parameter Transformed Divergence (TD) atau Jarak Jeffries-
Matusita (JM) yang memiliki kisaran nilai 0 hingga 2. Secara umum, indeks bernilai 81,9 menunjukkan bahwa objek secara spektral memang memiliki tingkat keterpisahan yang baik dan sudah memenuhi syarat untuk dilakukan proses klasifikasi. Nilai $<1$ menunjukkan bahwa sampel/klas yang bersangkutan sebaiknya digabung dengan sampel/klas lain (Richards \& Jia, 1999).

Uji akurasi lebih lanjut diupayakan dengan menggunakan "confusion matriks" dengan menggunakan ROI yang sebelumnya disimpan secara terpisah untuk menjaga independensi data. Uji akurasi dalam tahap pasca-klasifikasi ini diterapkan dengan menggunakan dua parameter, yaitu akurasi keseluruhan (overall accuracy) dan indeks Kappa (Congalton, 1991). Dalam proses pasca-klasifikasi peningkatan akurasi juga dapat diupayakan melalui penggabungan kelas yang memiliki separabilitas rendah (merging/combining classes) dan pemfilteran (Danoedoro, 2004). Berdasarkan kedua parameter ini, selanjutnya dipilih metode klasifikasi terbimbing yang memiliki nilai akurasi tertinggi untuk menghasilkan peta akhir yang menyajikan informasi penutup lahan dan bentuk lahan yang lengkap di lokasi penelitian. Proses analisis citra memanfaatkan gabungan dari software RS dan GIS yang meliputi ENVI, MapInfo, ArcGIS and ArcView 3.2 .

\section{Analisis Citra Satelit Berdasarkan Logika Samar}

Pada analisis citra satelit dengan logika samar, algoritma yang menghasilkan tingkat akurasi terbaik akan dijadikan dasar dalam pemilihan fungsi logika samar (Gaussian curve, Sigmoidally shaped atau Triangular-shaped). Hal ini dimaksudkan agar pada kedua analisis yang dibandingkan berangkat pada asumsi dasar yang sama tentang model distribusi nilai kecerahan piksel dari data citra yang akan dianalisis. Berbeda dengan klasifikasi biner yang membutuhkan ROI yang homogen/murni, maka analisis dengan logika samar kombinasi dari ROI yang homogen (tidak bercampur) dan ROI yang heterogen (bercampur) akan digunakan sebagaimana disarankan oleh Jansen, 2005. Data statistik nilai kecerahan piksel untuk setiap saluran terpilih yang menunjukkan kelas spektral tambak (TfP) akan digunakan sebagai data input pada fungsi keanggotaan (membership function), yang 
selanjutnya masing-masing berbentuk himpunan samar.

Hasil akhir peta lahan tambak existing dan potensial akan terbentuk dengan memanfaatkan gabungan himpunan samar (untuk masing-masing saluran) tersebut yang dihubungkan dengan operator fuzzy AND dan menggunakan fungsi implikasi MIN mengikuti metode penalaran fuzzy MAX-MIN (mamdani). Aturan (proposisi) yang digunakan klasifikasi fuzzy mamdani untuk penentuan wilayah tambak tersebut berbentuk:

"IF (band 5 is $\mathrm{mf} 1$ ) AND (band 4 is $\mathrm{mf} 2$ ) AND (band 3 is mf 3 ) THEN (kelas is Tambak)"

Untuk penalaran dengan metode mamdani ini, baik input (antesenden) dan output (konsekuen) sistem berupa himpunan samar. Dengan demikian peta wilayah tambak akan berbentuk himpunan logika samar, dengan tiap nilai piksel menunjukkan derajat keanggotaan untuk menjadi tambak.

\section{Analisis Data Elevasi}

Data elevasi dibuat dari kombinasi berbagai peta referensi. Peta-peta dasar tersebut antara lain adalah peta topografi, peta rupa bumi, dan peta batimetri yang diperoleh dari berbagai instansi seperti Bakosurtanal, Dinas Hidrooseanografi (Dishidros-AL), dan dari hasil pengukuran langsung di lapangan secara detil dengan menggunakan total station (NPL 302). Untuk daerah yang kurang memiliki data, dilakukan interpolasi dan ekstrapolasi data dengan mempertimbangkan profil ketinggian dari data SRTM (Shuttle Radar Topography Mission). Untuk memudahkan analisis nilai ketinggian untuk wilayah perairan (tambak dan laut) dijadikan 0. Estimasi lahan pantai yang masih potensial untuk dikembangkan menjadi tambak ekstensif mengacu pada kriteria kelayakan berdasarkan elevasi. Menurut Poernomo (1982), lahan pantai yang memiliki ketinggian 4 meter di atas permukaan laut ratarata tidak cocok untuk dikonversi menjadi tambak ekstensif, sebab ini membutuhkan biaya konstruksi yang tinggi. Lokasi yang ideal untuk tambak ekstensif seharusnya berada sekitar 0,3 hingga 1,2 meter di atas muka laut rata-rata (Yamashita \& Sutardjo, 1977). Informasi ini akan digunakan dalam analisis logika samar untuk pendefinisian lahan tambak existing dan potensial.

\section{HASIL DAN BAHASAN}

Hasil evaluasi saluran-saluran terbaik dari citra landsat-7 ETM $^{+}$yang digunakan untuk daerah pantai (pertambakan).

Rangkuman hasil analisis statistik univariat dan multivariat citra Landsat $7 \mathrm{ETM}^{+}$yang digunakan dalam penelitian ini dapat dilihat pada Lampiran 1. Berdasarkan analisis tersebut diketahui saluran inframerah dekat dan tengah $(4,5$, dan 7) memiliki nilai korelasi yang tinggi ( $r$ 8 0,81$)$ satu sama lain yang berarti, kalau ketiganya dikombinasikan tidak akan menghasilkan informasi yang baru malah akan terjadi pemborosan karena perulangan (redundant). Selain itu, dari nilai maksimum dan minimum spektral terlihat jika ketiganya memiliki nilai minimum 0 , hal ini disebabkan lahan umumnya tersusun oleh wilayah perairan yang menyerap radiasi inframerah dekat dan tengah hingga mengakibatkan rendahnya pantulan dari saluran-saluran tersebut. Oleh karena itu, kombinasi ketiga band tersebut harus dihindari untuk kawasan pantai khususnya dalam identifikasi lahan pertambakan. Tingkat korelasi yang tinggi juga terlihat antara saluran 2 dan $3(r=0,92)$, sehingga kombinasi ini juga perlu dihindari. Dan jika dibandingkan dengan ketiga saluran visibel $(1,2$, dan 3$)$, saluran 4 memiliki tingkat redundant yang lebih rendah. Saluran ini jika dikombinasikan dengan ke-5 saluran lainnya juga akan menghasilkan nilai kovarian yang lebih tinggi. Sehingga untuk mendapatkan informasi yang lebih baik (bervariasi) dalam kombinasi saluran, maka saluran 4 ini seharusnya dilibatkan. Sampai di sini, meskipun telah diketahui saluran potensial yang bakal memberikan tingkat akurasi sekaligus informasi yang lebih banyak, akan tetapi dari data statistik ini belum diketahui secara pasti mengenai kombinasi terbaik (minimal kombinasi 3 saluran).

Jika digunakan 6 saluran dan analisis dibatasi hanya pada tiga saluran maka menurut teori kombinasi seharusnya kita mengevaluasi 20 jenis kombinasi saluran. Dua metode yang umum dipakai dalam mengevaluasi ke-20 jenis kombinasi tersebut antara lain adalah optimum index factor (OIF) dan Sheffield Indeks (SI). Dari hasil analisis diketahui, jika kombinasi terbaik berdasakan nilai OIF yang didasari pada total varians dan korelasi antara kombinasikombinasi saluran-saluran hanya cocok 
Tabel 1. Penentuan kombinasi 3 saluran terbaik dari 20 kombinasi yang mungkin dengan menggunakan Indeks sheffield (SI) untuk 6 saluran Landsat-7 $\mathrm{ETM}^{+}$wilayah Pidie

Table 1. Determination of the best 3 bands combination from 20 possible band combinations based on sheffield index (SI) for six bands of Landsat-7 $\mathrm{ETM}^{+}$of the Pidie

\begin{tabular}{|c|c|c|c|}
\hline \multirow{2}{*}{$\begin{array}{c}\text { Ranking } \\
\text { Rank }\end{array}$} & \multicolumn{2}{|r|}{ SI } & \\
\hline & $\begin{array}{l}\text { Nilai } \\
\text { Value }\end{array}$ & $\begin{array}{l}\text { Kombinasi } \\
\text { Combination }\end{array}$ & \\
\hline 1 & 4828361 & 345 & $S I=|\operatorname{Cov} p \times p|$ \\
\hline 2 & 3274659 & 347 & \\
\hline 3 & 2826172 & 245 & $|\operatorname{Cov} \mathrm{p} \times \mathrm{p}|=$ determinan matriks \\
\hline 4 & 1962675 & 247 & kovarian pada sub-set $p$ \\
\hline 5 & 1890514 & 134 & \\
\hline 6 & 1586914 & 135 & $\mathrm{P}=3$ kare na kita sedang \\
\hline 7 & 1187590 & 147 & mengevaluasi 3 kombinasi band \\
\hline 8 & 1107669 & 234 & yang optimal \\
\hline 9 & 906862.7 & 357 & \\
\hline 10 & 904697.1 & 145 & \\
\hline 11 & 872105.8 & 235 & \\
\hline 12 & 853525.7 & 124 & \\
\hline 13 & 814157.9 & 457 & \\
\hline 14 & 761849.5 & 125 & \\
\hline 15 & 546945.6 & 257 & \\
\hline 16 & 416313 & 137 & \\
\hline 17 & 342924.4 & 157 & \\
\hline 18 & 227702.4 & 237 & \\
\hline 19 & 201962.9 & 127 & \\
\hline 20 & 66219.53 & 123 & \\
\hline
\end{tabular}

diterapkan jika analisis dilakukan secara visual. Namun karena dalam penelitian ini dilakukan klasifikasi multispektral terbimbing yang mengandalkan pada otomatisasi ROI maka hanya nilai SI yang didasarkan pada determinan matriks kovarian dari ukuran subset $\mathrm{p}$ (dalam hal ini $p=3$ saluran) yang ditampilkan. Dari nilai SI diketahui 4 kombinasi secara berurutan memiliki nilai yang tertinggi yakni kombinasi saluran 345, 347, 245, dan 247 (Tabel 1). Kehadiran saluran 4 pada keempat kombinasi saluran terbaik tersebut seirama dengan saran dari analisis statistik sebelumnya. Namun demikian untuk lebih memastikan selanjutnya kombinasi terbaik ini dapat dibandingkan dengan nilai akurasi (akurasi keseluruhan dan
Indeks kappa) untuk metode klasifikasi terbimbing terbaik yang diuji untuk ke-20 kombinasi yang sama.

\section{Model Penutup/Penggunaan Lahan Kawasan Pantai Kembang Tanjung Berdasarkan Logika Biner}

Dari 20 hasil kombinasi yang dilakukan pada metode klasifikasi tak terbimbing, dipilih 10 pasangan yang menunjukkan kombinasi antara tutupan/penggunaan lahan dan bentuk seperti yang tercantum pada Tabel 2 . Kualitas pemisah dari ROIs yang dibuat berdasarkan ke-10 pasangan tersebut ini dapat dilihat pada Lampiran 1. Dari pasangan kategori-kategori tersebut terdapat kategori-kategori yang 
Tabel 2. Kombinasi 10 tutupan/penggunaan dan bentuk lahan yang terpilih untuk digunakan dalam klasifikasi multispektral terbimbing

Table 2. The 10 selected combinations of land use-cover and land form used in supervised image classification

\begin{tabular}{|c|c|}
\hline $\begin{array}{l}\text { Kode } \\
\text { Code }\end{array}$ & $\begin{array}{l}\text { Ket erangan } \\
\text { Description }\end{array}$ \\
\hline TfV1 & $\begin{array}{l}\text { Dataran pasang surut dengan vegetasi (bukan-mangrove) } \\
\text { Tidal flat with vegetation (non-mangrove) }\end{array}$ \\
\hline TfVm & $\begin{array}{l}\text { Dataran pasang surut de ngan mangrove } \\
\text { Tidal flat with mangrove }\end{array}$ \\
\hline TfB & $\begin{array}{l}\text { Dataran pasang surut atau lahan kosong } \\
\text { Tidal flat or barren land }\end{array}$ \\
\hline TfM & $\begin{array}{l}\text { Dataran pasang surut atau dataran lumpur } \\
\text { Tidal flat or mud flat }\end{array}$ \\
\hline TfP & $\begin{array}{l}\text { Dataran pasang surut dengan tambak } \\
\text { Tidal flat with ponds (Brackishwater ponds) }\end{array}$ \\
\hline $\mathrm{ApF}$ & $\begin{array}{l}\text { Dataran alluvial dengan lahan pertanian } \\
\text { Alluvial plain with agriculture field }\end{array}$ \\
\hline ApFdf & $\begin{array}{l}\text { Dataran alluvial dengan lahan pertanian kering } \\
\text { Alluvial plain with dry agriculture field }\end{array}$ \\
\hline $\mathrm{ApV}$ & $\begin{array}{l}\text { Dataran alluvial dengan vegetasi lain } \\
\text { Alluvial plain with other vegetation }\end{array}$ \\
\hline ApS & $\begin{array}{l}\text { Dataran alluvial dengan pemukiman } \\
\text { Alluvial plain with residential area }\end{array}$ \\
\hline RS & $\begin{array}{l}\text { Sedimen (umumnya berasal dari de posisi sungai: pasir dan lumpur) } \\
\text { Sediment (mainly from river deposits : sand or colloid silt) }\end{array}$ \\
\hline
\end{tabular}

sangat susah untuk dipisahkan (tingkat bercampur yang tinggi). Pasangan kelas yang memiliki nilai separabilitas yang rendah tersebut antara lain TfB-TfM, TfV1-ApS dan TfV2m-TfP dengan nilai keterpisahan masingmasing 1,$1641 ; 1,2219$; dan 1,3927.

Tingkat akurasi dapat diketahui dari akurasi keseluruhan dan nilai indeks kappa. Dengan memanfaatkan seluruh band (terkecuali band 6) diperoleh tingkat akurasi paling tinggi pada metode klasifikasi biner dengan algoritma maximum likelihood dengan akurasi keseluruhan 86,6268\% (Indeks kappa = 0,8278 ) dibandingkan beberapa metode lain seperti neural net dan parallelepiped dengan masing-masing akurasi keseluruhan 36,75 (indeks kappa $=0,16$ ) dan 20,70 (indeks kappa =0,17). Sedangkan Minimun distance memiliki nilai tingkat akurasi yang hampir sama dengan maximum likelihood (akurasi keseluruhan =
$82,50 \%$ dan indeks kappa $=0,77)$. Setelah dilakukan proses penggabungan dan pemfilteran mayoritas selektif tingkat akurasi dari maximum likelihood tersebut meningkat hingga $92,28 \%$ (indeks kappa $=0,89$ ). Nilai tersebut sudah cukup bagus bila dibandingkan dengan nilai ambang akurasi $85 \%$ bagi penerimaan suatu hasil interpretasi (Campbell, 1983; Danoedoro, 2004). Output langsung dari klasifikasi spektral dengan metode maximum likelihood dan minimum distance ditampilkan pada Gambar 1. Tingkat akurasi yang konsisten juga bisa didapatkan dengan hanya menggunakan 3 jenis kombinasi band. Dari hasil pengujian metode maximum likelihood untuk ke-20 kombinasi band pada Tabel 1 sebelumnya diperoleh nilai akurasi tertinggi didapatkan pada klasifikasi spektral dengan memanfaatkan saluran 345, 347, 245, dan 247 dengan masing-masing nilai akurasi 

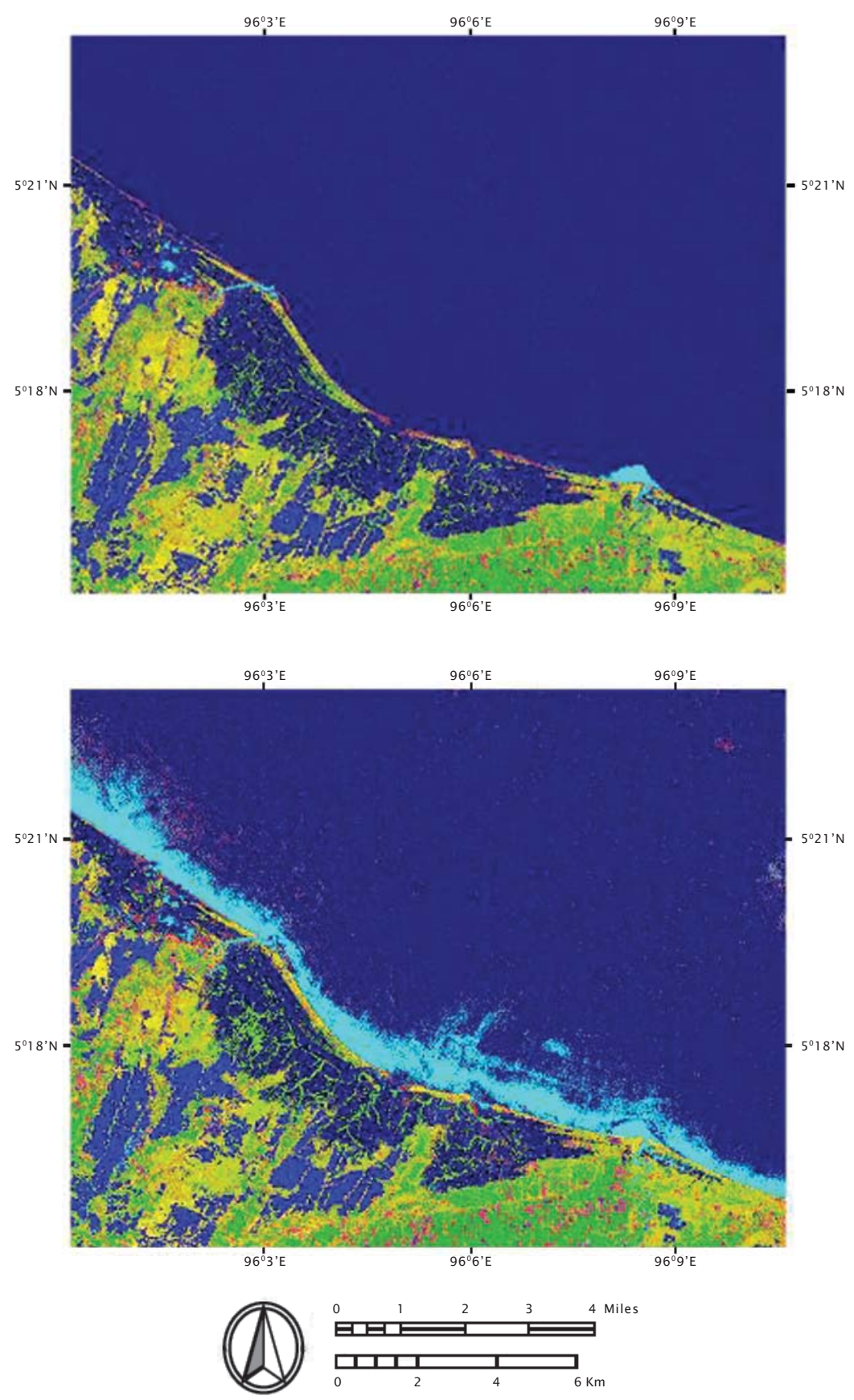

Gambar 1. Peta terbaik hasil klasifikasi biner dengan metode klasifikasi terbimbing: a) metode minimum distance dan b) metode maximum likelihood

Figure 1. Maps showing the two best results of supervised classification: (a) = Minimum distance classifier and (b) Maximum likelihood classifier 
keseluruhan dan indeks kappa; $86,56 \%(0,83)$, $85,65 \%(0,81), 83,39(0,79)$, dan 83,05 $(0,78)$. Urutan kombinasi terbaik ini sama dengan yang disarankan dengan menggunakan sheffield Index (SI) sebelumnya. Namun dalam aplikasinya perlu dicatat bahwa keefektifan metode maximum likelihood sangat tergantung pada estimasi akurat pada vektor ratarata dan matriks kovarian, sehingga nilai akurasi yang tinggi pada metode ini harus didukung oleh tersedianya ROI yang cukup untuk masing-masing kelas spektral (Jensen, 2005; Richards \& Jia, 1999).

Meskipun pada hasil langsung klasifikasi spektral dengan metode maximum likelihood menunjukkan nilai akurasi yang tinggi namun masih terlihat dengan jelas kesalahan pixel secara spasial (geometri). Hal ini dapat dimaklumi karena pengujian dilakukan hanya dengan menggunakan ROI yang diambil pada beberapa lokasi terseleksi juga secara alamiah tidak homogen. Oleh karena itu, klasifikasi akhir diselesaikan dengan mengandalkan pengetahuan lokal dan peta acuan digital dengan program GIS dan hasilnya dikonversi ke vektor untuk perhitungan luas total masingmasing kelas. Peta klasifikasi akhir penutup/ penggunaan lahan pantai di Kecamatan Kembang Tanjung yang didasari logika biner dapat dilihat pada Gambar 2. Kelas-kelas penutup/penggunaan lahan pada hasil akhir ini telah disederhanakan dari 10 kelas menjadi 8 kelas dalam proses penggabungan kelas pada proses pasca-klasifikasi. Kedelapan jenis tutupan/penggunaan lahan tersebut dapat dilihat pada Gambar 2. Peta tutupan dan penggunaan lahan ini sudah dapat digunakan untuk keperluan perencanaan yang membutuhkan estimasi global mengenai jenis dan sebaran penutup dan penggunaan lahan.

\section{Klasifikasi Citra dan Identifikasi Lahan Tambak dengan Logika Samar}

Pada hasil analisis di atas diketahui bahwa hasil klasifikasi citra dengan algoritma Maximum likelihood memiliki tingkat akurasi tertinggi dibandingkan beberapa algoritma lainnya. Algoritma metode klasifikasi biner ini didasarkan pada distribusi normal (gaussian). Dengan demikian sudah bisa dipastikan jika nilai piksel ROI yang digunakan secara statistik berdistribusi normal. Hal ini terbukti pada analisis histogram nilai kecerahan piksel pada Gambar 3 (A) dan 3 (B) untuk data ROI-TfP pada

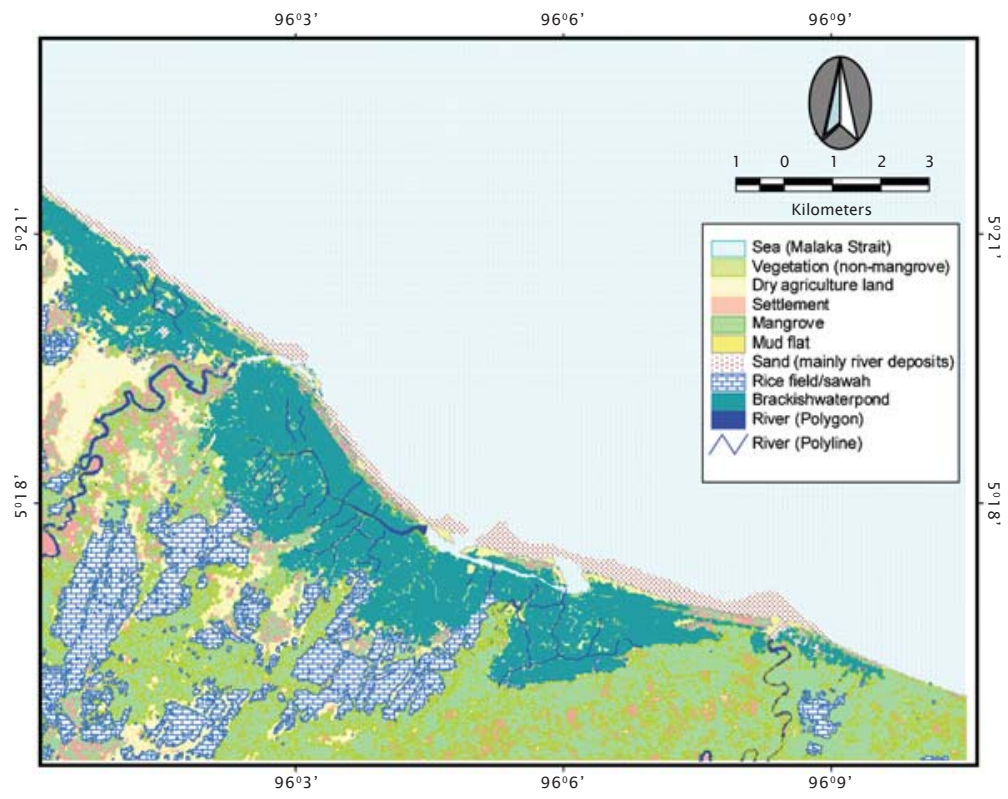

Gambar2. Hasil akhir klasifikasi tutupan/penggunaan lahan dengan metode maximum likelihood yang ditingkatkan

Figure 2. Final land cover-use map from supervised classification based on an enhanced maximum likelihood classifier 

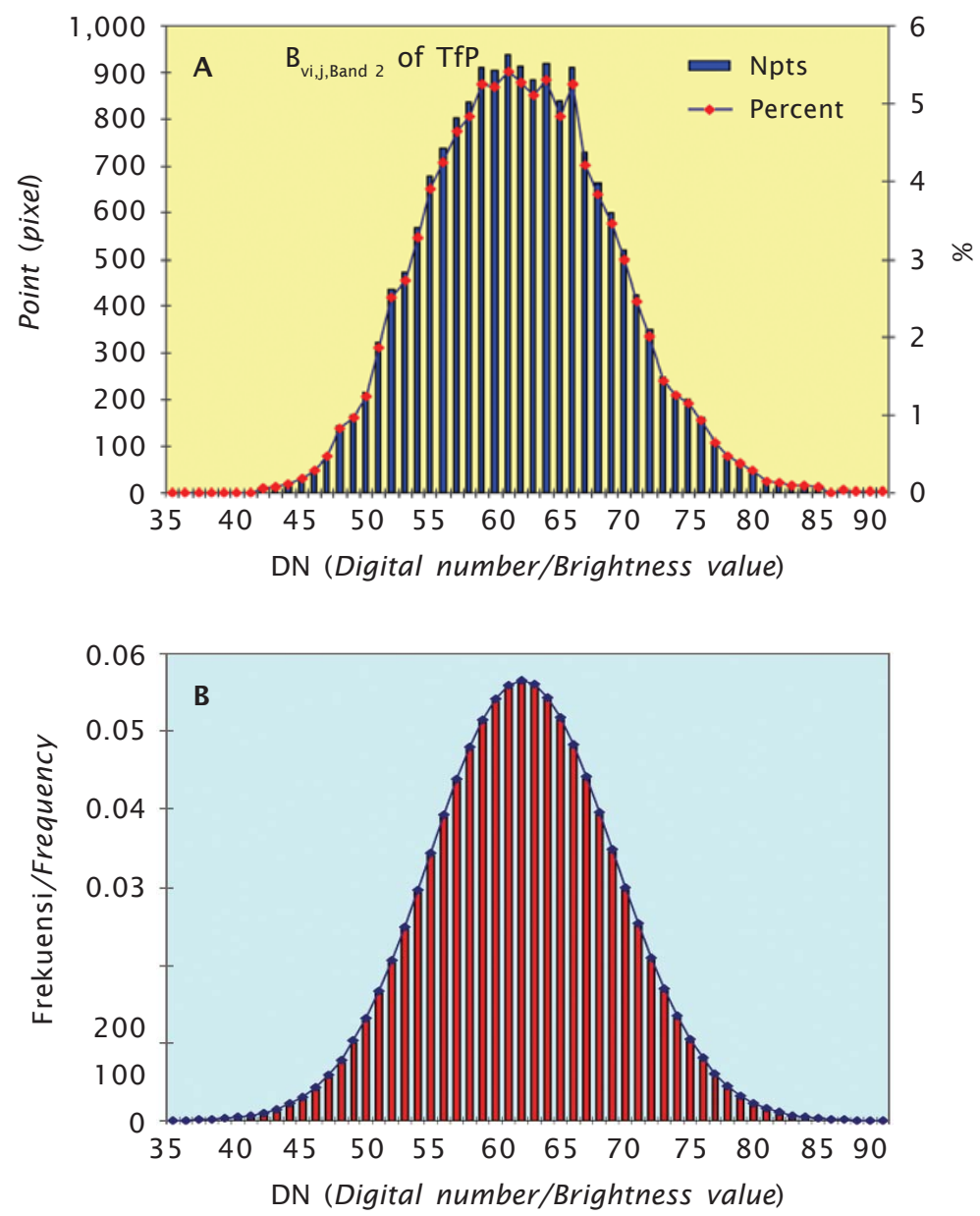

Gambar 3. Contoh analisis histogram kecerahan piksel untuk ROI-TfP. (A) histogram kecerahan piksel asli, (B) Tranformasi data asli mengikuti distribusi normal (Gaussian)

Figure 3. An example of histogram analysis using band 2 of ROITfP. (A) histogram of original brightness value (BV) of image (raw image), (B) transformation of original image value to a Gaussian function

salah satu saluran yang membentuk kurva distribusi normal. Dengan dasar ini pendekatan analisis dengan logika samar juga dilakukan dengan memanfaatkan fungsi keanggotaan gaussian (Gaussmf). Dan nilai piksel untuk ROITfP untuk saluran 5,4,3 dijadikan data dasar dalam analisis untuk penentuan daerah tambak mengingat bahwa meskipun hanya terbentuk kombinasi ketiga saluran namum hasil klasifikasinya tetap memiliki tingkat ketelitian yang hampir sama dengan hasil analisis yang melibatkan seluruh saluran.
Hasil analisis statistik nilai kecerahan piksel untuk ROI-TfP (tambak) pada masing-masing saluran 5, 4, dan 3 terangkum pada Tabel 3. Nilai standar deviasi dan rata-rata kecerahan piksel untuk setiap saluran setelah di-input dalam fungsi keanggotaan gauss:

$$
f(x ; \sigma, c)=e \frac{-(x-c)^{2}}{2 \sigma^{2}}
$$

di mana: $\mathrm{c}=$ nilai tengah dari $\mathrm{ROI}(\mathrm{ROI}$ mean value) dan ó $=$ Standard deviasi terlihat pada 
Tabel 3. Rata-rata dan standar deviasi ROI untuk tambak air payau

Table 3. Mean and standard deviation values of ROI identifying brackishwater ponds

\begin{tabular}{ccc}
\hline Saluran (Band) & Rata-rata (Mean) & Standar deviasi (Stdev) \\
\hline 3 & 54.00 & 8.92 \\
4 & 21.83 & 12.11 \\
5 & 22.88 & 13.05 \\
\hline
\end{tabular}

Gambar 4. Pada Gambar 4 dapat diketahui bahwa kelas spektral tambak memiliki derajat keanggotaan yang sama pada saluran 5 dan 4 sesuai dengan hasil analisis statistik sebelumnya. Dengan demikian untuk analisis dengan logika samar, kombinasi 2 saluran (4-3 atau 5-3) saja sudah cukup untuk mendefinisikan wilayah tambak. Model ini juga bisa diaplikasikan untuk kelas spektral (kategori penutup lahan) lainnya, asalkan dilakukan analisis statistik nilai kecerahan piksel bersesuaian.

Pada Gambar 5 ditampilkan dua hasil klasifikasi lahan tambak dengan membandingkan hasil terbaik dari metode klasifikasi standar dengan algoritma maximum likelihood dan hasil klasifikasi dengan logika samar. Pada klasifikasi standar, terlihat jika metode ini kurang mampu memisahkan antara wilayah laut dengan tambak, sehingga perlu pengetahuan lokal yang memadai dalam memperbaiki hasil klasifikasi akhir. Dengan memanfaatkan saluran yang sama, metode klasifikasi dengan logika samar telah mampu memisahkan kelas tambak dengan kelas-kelas lainnya hingga ketelitian ukuran piksel. Areal yang secara tegas diklasifikasikan oleh metode standar, untuk klasifikasi dengan logika samar masih nampak bervariasi, sehingga nampak lebih menyerupai kondisi alamiah. Karena pada dasarnya di daerah pertambakan masih dapat dijumpai kelas-kelas lain seperti perkebunan, pemukiman atau lahan-lahan kosong yang belum dikonversi menjadi tambak.

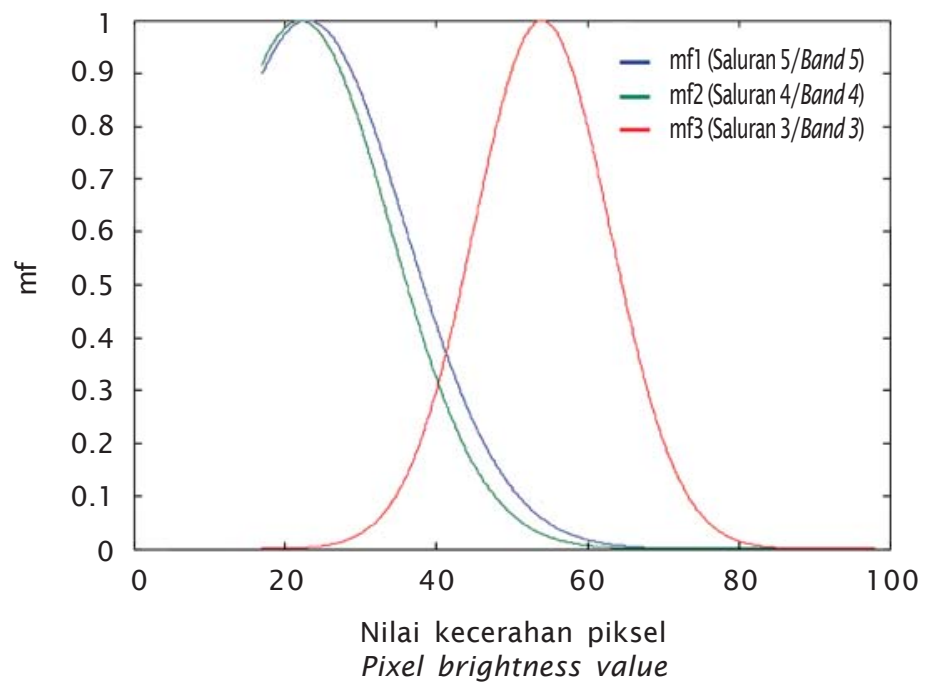

Gambar 4. Contoh representasi fungsi keanggotaan ( $\mathrm{mf}$ ) tiap band $(5,4$, dan 3 ) untuk kategori tambak dengan menggunakan fungsi gaussmf di Matlab

Figure 4. An example of plotting membership function ( $\mathrm{mf}$ ) of each band (5,4, and 3) to identify fish pond area 

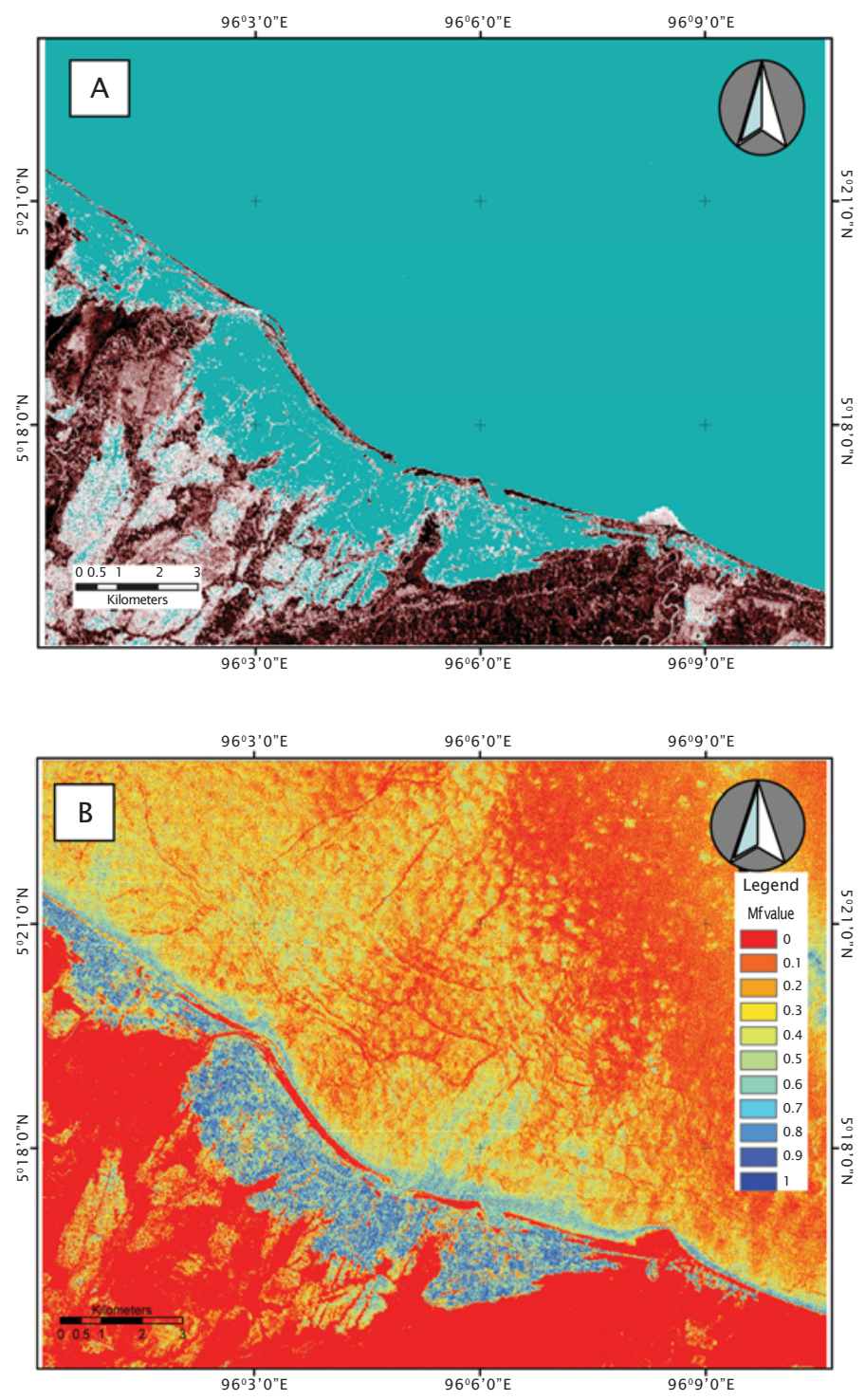

Gambar 5. Perbandingan hasil klasifikasi antara (A) klasifikasi biner (maximum likelihood) dan (B) klasifikasi dengan logika samar

Figure 5. Comparison between (A) binary classification (maximum likelihood) and (B) fuzzy classification

\section{Estimasi Potensi Pengembangan Lahan Berdasarkan Kriteria Elevasi untuk Lahan Tambak Ekstensif}

Salah satu yang cukup menarik dalam lingkungan budidaya adalah estimasi yang akurat mengenai lahan yang kemungkinan akan dikembangkan (dikonversi) menjadi tambak. Jika tutupan/penggunaan lahan akhir klasifikasi ditumpangsusun (overlay) dengan data elevasi digital maka akan tergambar model bentang alam 3 dimensi seperti pada Gambar 6. Dari model tiga dimensi tersebut sudah dapat diestimasi secara simpel lokasi-lokasi lahan mana saja yang kemungkinan masih dapat dikonversi menjadi tambak dan yang 


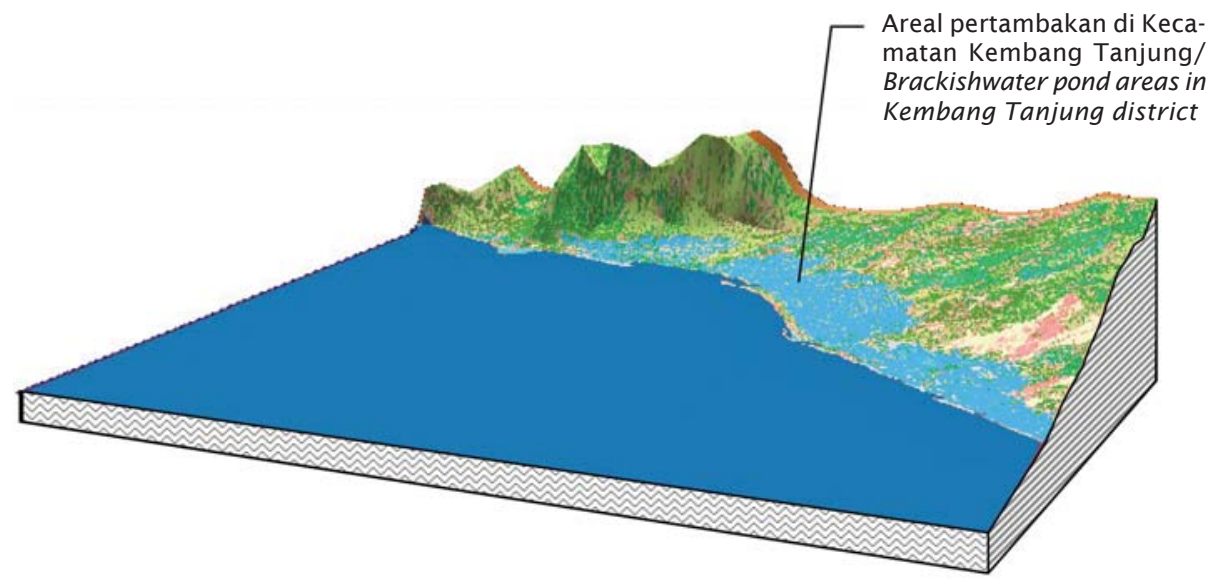

Gambar 6. Peta hasil klasifikasi akhir penutup/penggunaan lahan yang ditumpang tindih dengan data elevasi digital

Figure 6. Final land use/cover map overlaid with digital elevation data

sama sekali tidak memungkinkan lagi, sebagai contoh sawah dataran pasang surut $(<4$ m dari permukaan laut) yang berbatasan langsung dengan tambak kemungkinan besar akan berubah fungsi menjadi tambak, sebaliknya daerah dengan elevasi (> $5 \mathrm{~m}$ ) termasuk perbukitan sudah pasti tidak akan dikonversi menjadi tambak ekstensif sehubungan dengan prasyarat lahan (mengandalkan pasokan air pasang surut dan biaya konstruksi). Namun karena peta tutupan/penggunaan lahan yang dibentuk dari hasil klasifikasi biner dengan

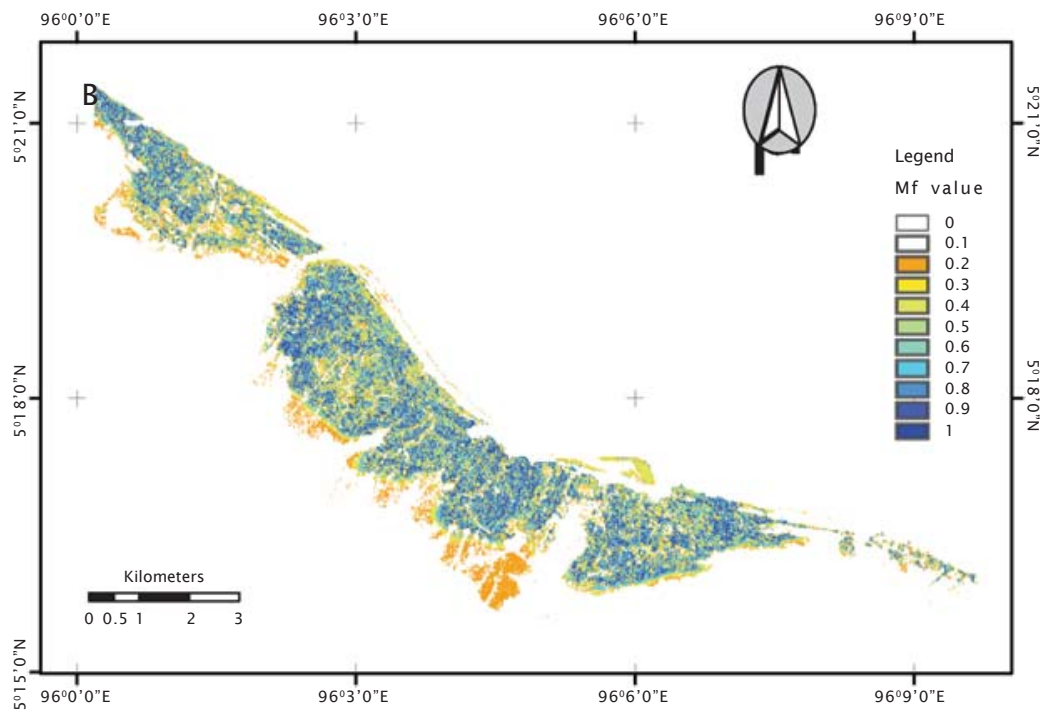

Gambar 7. Peta potensi lahan tambak dengan logika samar yang memadukan hasil klasifikasi tambak dan hasil klasifikasi lahan berdasarkan elevasi

Figure 7. A map showing potential pond area following fuzzy logic rules combined with a pre-determined pond area and extensive brackishwater ponds area based on digital elevation data 
Tabel 4. Perbandingan hasil perhitungan dengan metode klasifikasi logika biner dan klasifikasi logika samar untuk penentuan luas lahan tambak dengan melibatkan kriteria elevasi lahan untuk tambak air payau pola ekstensif

Table 4. Comparison of total pond area calculated from binary and fuzzy classifications by integrating land elevation criteria for extensive brackishwater aquaculture

\begin{tabular}{ccc}
\multirow{2}{*}{$\begin{array}{c}\text { Klasifikasi biner } \\
\text { Binary/boolean classification } \\
\text { (maximum likelihood) }\end{array}$} & $\begin{array}{c}\text { Klasifikasi dengan logika samar } \\
\text { Fuzzy Classification }\end{array}$ \\
\cline { 2 - 3 } (ha) & $\begin{array}{c}\text { Fungsi keanggotaan } \\
\text { Membership function }\end{array}$ & $\begin{array}{c}\text { Luas } \\
\text { Area (ha) }\end{array}$ \\
\hline $\mathbf{1 , 9 7 2 . 0}$ & 1 & $\mathbf{1 , 2 5 4 . 0}$ \\
& 0.9 & $\mathbf{5 1 7 . 0}$ \\
& 0.8 & 300.4 \\
0.7 & 138.9 \\
& 0.6 & 93.9 \\
0.5 & 124.1 \\
& 0.4 & 269.2 \\
& 0.3 & 138.9 \\
& 0.2 & 249.7 \\
& 0.1 & $6,853.0$ \\
\end{tabular}

garis tegas, sehingga menyulitkan mengetahui kecenderungan perubahan kelas-kelas penutup/penggunaan lahan yang saling berdampingan.

Sedangkan pada hasil klasifikasi peta dengan logika samar, lokasi dan sebaran lahan yang sudah dimanfaatkan sebagai tambak dan yang belum dimanfaatkan dapat diestimasi dari nilai derajat keanggotaannya. Sehingga arah potensial pengembangan tambak berdasarkan kriteria elevasi lahan juga dapat diprediksi dari nilai tersebut.

Pada Gambar 7 terlihat jika peta wilayah tambak dipresentasikan dalam bentuk nilai derajat keanggotaan tiap piksel. Pada setiap kategori derajat keanggotaan tersebut dihitung luas lahannya seperti yang tercantum pada Tabel 4. Berdasarkan data Tabel 4, diketahui luas lahan tambak dengan menggunakan klasifikasi biner hampir sama dengan hasil penjumlahan luas lahan untuk dua fungsi keanggotaan tertinggi dari klasifikasi dengan logika samar. Dengan demikian dalam menghitung luas lahan tambak pada peta hasil klasifikasi tersebut, dapat dilakukan dengan mengambil total luas lahan yang ditunjukkan pada nilai fungsi keanggotaan tertinggi (nilai fungsi keanggotaan 0,9 dan 1,0). Proses ini dikenal dengan proses defusifikasi, di mana input dari proses ini berupa himpunan fuzzy yang diperoleh dari komposisi dari aturanaturan fuzzy, sedangkan output yang dihasilkan merupakan suatu bilangan pada domain himpunan fuzzy tersebut.

\section{KESIMPULAN}

Dari hasil penelitian ini, dapat disimpulkan tiga hal penting sebagai berikut:

- Identifikasi potensi lahan tambak ekstensif secara cepat dengan ketelitian yang memadai dan memanfaatkan citra landsat-7 $\mathrm{ETM}^{+}$dapat diupayakan dengan sistem klasifikasi multispektral standar dengan algoritma maximum likelihood. Persyaratannya dilakukan pengontrolan ketat prosedur klasifikasi yang meliputi pengambilan sampel secara cermat yang diikuti oleh analisis separabilitas dan pemrosesan pasca-klasifikasi yang disertai dengan data estimasi kesalahan didasarkan pada pengertian yang mendalam mengenai sumber dan tipe kesalahan. 
- Penilaian kualitas citra melalui analisis statistik univariat dan multivariat menggunakan nilai kecerahan piksel untuk daerah training (ROI) mampu memberikan saran kombinasi saluran terbaik yang dapat digunakan untuk mengidentifikasi penutup/penggunaan lahan kawasan pantai secara umum dan secara khusus untuk identifikasi wilayah tambak dengan tingkat akurasi yang cukup baik tanpa harus melibatkan seluruh saluran yang ada demi penghematan memori perhitungan dan menghindari pemborosan informasi.

- Pendekatan klasifikasi citra landsat-7 ETM+ dengan logika samar mampu memperlihatkan hasil klasifikasi yang sangat baik untuk menentukan batas tambak yang tidak bisa dilakukan secara langsung bahkan oleh metode standar dengan algoritma terbaik. Dan dengan penambahan satu variabel kunci untuk tambak ekstensif seperti elevasi dalam klasifikasi, klasifikasi dengan logika samar dapat digunakan untuk memprediksi potensi pengembangan lahan budidaya tambak ekstensif dan kemungkinan tumpang tindih dengan penggunaan lahan lainnya. Gradasi fungsi keanggotaan tiap piksel juga dapat digunakan dalam dalam penelitian ekologi di wilayah pertambakan.

\section{DAFTAR ACUAN}

DKP. 2005. Revitalisasi perikanan budidaya, 2006-2009. Departemen Kelautan dan Perikanan. Jakarta, $275 \mathrm{pp}$.

DKP. 2003. Master plan pengembangan budidaya air payau di Indonesia. Dirjen Perikanan Perikanan Budidaya, Departemen Kelautan dan Perikanan. Jakarta, 250 pp.

Burrough, P.A. \& McDonnell, R.A. 1998. Principles of Geographical Information Systems. Oxford University Press Inc. New York, $333 \mathrm{pp}$.

Campbell, J.B. 1983. Mapping the land: Areal Imagery for land use information. Association of American Geographers. Washington, D.C., 50 pp.

Chak, C.K. \& Feng, G. 1998. Implementation of fuzzy systems. In Leondes. C.T. (ed). Fuzzy logic and expert systems applications. Sixth edition Academic press. New York, p. 57-121.

Congalton, R.G. 1991. A review of assessing the accuracy of classifications of remotely sensed data. Photogrammetric Engineering \& Remote Sensing. (37): 35 - 46.

Danoedoro, P. 2004. Klasifikasi penutup lahan secara rinci: pengalaman dengan citra landsat $\mathrm{ETM}^{+}$dan QuickBird. In Danoedoro. P. (Ed.). Sains informasi geografis. Jurusan Kartografi dan Penginderaan Jauh Fakultas Geografi UGM. Yogyakarta, p. 147-176.

Falzarano, S.R. \& Thomas, K.A. 2004. Fuzzy set and spatial analysis techniques for evaluating thematic accuracy of a landcover map. In Lunetta. R.S. and Lyon. J.G. (Eds). Remote sensing and GIS accuracy assessment. CRC press. New York, p. 189205.

Gopal, S. \& Woodcock, C. 1994. Theory and methods for accuracy assessment of thematic maps using fuzzy sets, Photogram, Engineering, Remote sens., 60:181-188.

Jensen, J.R. 2005. Introductory digital image processing: a remote sensing perspective. Third edition. Pearson prentice hall, Upper saddle, NJ, $526 \mathrm{pp}$.

Kasabov, N.K. 1996. Foundations of neural networks, fuzzy systems, and knowledge engineering. Massachusetts Institute of Technology Press. London, 550 pp.

Kusumadewi, S. 2002. Analisis dan desain system fuzzy menggunakan tool box matlab. Graha Ilmu. Yogyakarta, 276 pp.

Poernomo, A. 1982. Pembuatan tambak udang di Indonesia. Departemen Pertanian, Badan Penelitian dan Pengembangan Pertanian, Balai Penelitian Perikanan Budidaya Pantai. Maros, $40 \mathrm{pp}$

Richards, J.A. \& Jia, X. 1999. Remote sensing digital image analysis: an introduction. Third, revised and enlarged edition. Springer. New York, 363 pp.

Yamashita, M. \& Sutardjo. 1977. Engineering aspects of brackishwater pond culture in Indonesia. "Technical report of the SCSP/ SEAFDEC: workshop on Aquaculture Engineering Volume 2". Manila. p. 261-280. 
Lampiran 1. Data statistik citra Landsat-7 ETM+ terseleksi untuk daerah Pidie dengan memanfaatkan 6 saluran (1, 2, 3, 4, 5, dan 7)

Appendix 1. Statistics for the Pidie coastal areas. Sub-scene of landsat-7 ETM+ composed of six bands (1, 2, 3, 4, 5, and 7)

\begin{tabular}{|c|c|c|c|c|c|c|}
\hline St at S & Min & Max & Mean & Stdev & & \\
\hline Band 1 & 59 & 200 & $8,001,123$ & $5,712,109$ & & \\
\hline Band 2 & 28 & 173 & $5,407,904$ & $1,066,463$ & & \\
\hline Band 3 & 14 & 198 & $4,281,753$ & $1,379,078$ & & \\
\hline Band 4 & 0 & 207 & $2,986,743$ & $3,248,171$ & & \\
\hline Band 5 & 0 & 217 & $3,043,777$ & $2,945,448$ & & \\
\hline Band 7 & 0 & 195 & $2,054,982$ & $1,336,655$ & & \\
\hline $\mathrm{ce}$ & Band 1 & Band 2 & Band 3 & Band 4 & Band 5 & Band 7 \\
\hline Band 1 & $3,262,819$ & $2,729,622$ & $3,152,339$ & $-482,625$ & $-286,505$ & $-299,088$ \\
\hline Band 2 & $2,729,622$ & $1,137,344$ & $1,359,556$ & $1,992,941$ & $1,910,802$ & 886,273 \\
\hline Band 3 & $3,152,339$ & $1,359,556$ & $1,901,857$ & $2,252,455$ & $2,374,795$ & $1,174,533$ \\
\hline Band 4 & $-482,625$ & $1,992,941$ & $2,252,455$ & $1,055,061$ & $8,930,693$ & 350,992 \\
\hline Band 5 & $-286,505$ & $1,910,802$ & $2,374,795$ & $8,930,693$ & $8,675,664$ & 374,192 \\
\hline Band 7 & $-299,088$ & 886,273 & $1,174,533$ & 350,992 & 374,192 & $1,786,646$ \\
\hline on & Band 1 & Band 2 & Band 3 & Band 4 & Band 5 & Band 7 \\
\hline Band 1 & 1 & 0.448085 & 0.400173 & -0.26012 & -0.17029 & -0.03917 \\
\hline Band 2 & 0.448085 & 1 & 0.924405 & 0.57532 & 0.608301 & 0.621731 \\
\hline Band 3 & 0.400173 & 0.924405 & 1 & 0.502838 & 0.584636 & 0.637173 \\
\hline Band 4 & -0.26012 & 0.57532 & 0.502838 & 1 & 0.933458 & 0.808424 \\
\hline Band 5 & -0.17029 & 0.608301 & 0.584636 & 0.933458 & 1 & 0.950438 \\
\hline Band 7 & -0.03917 & 0.621731 & 0.637173 & 0.808424 & 0.950438 & 1 \\
\hline
\end{tabular}


Lampiran 2. Evaluasi tingkat keterpisahan antara kategori-kategori penutuppenggunaan lahan dengan indikator indeks Jefries-Matsusita

Appendix 2. Separability measures among land use-cover categories indicated by values of Jefries-Matsusita index

\begin{tabular}{|c|c|}
\hline Pasangan kelas-kelas daerah latihan (Pair of ROI classes) & Jefries-mat susita \\
\hline TfB (3793 titik/points) and TfM (998 titik/points) & 11,641 \\
\hline TfV1 (9511 titik/points) and ApS (1422 titik/points) & 12,219 \\
\hline TfV2m (1 524 titik/points $)$ and TfP (6671 titik/points ) & 13,927 \\
\hline TfVI (9511 titik/points) and ApV(2236 titik/points ) & 14,285 \\
\hline TfB (3793 titik/points) and ApF2dpf (3502 titik/points) & 14,731 \\
\hline ApV (2236 titik/points) and ApS (1422 titik/points) & 15,750 \\
\hline RS (899 titik/points) and ApF (8078 titik/points) & 16,341 \\
\hline TfVI (9511 titik/points) and TfB (3793 titik/points) & 17,485 \\
\hline TfV2m (1524 titik/points) and ApF (8078 titik/points) & 17,521 \\
\hline TfV1 (9511 titik/points) and TfV2m (1524 titik/points) & 18,071 \\
\hline TfV1 (9511 titik/points) and ApF2dpf (3502 titik/points) & 18,105 \\
\hline TfB (3793 titik/points) and ApS (1422 titik/points) & 18,469 \\
\hline RS (899 titik/points) and TfP (6671 titik/points) & 18,882 \\
\hline TfB (3793 titik/points) and ApF (8078 titik/ points) & 18,967 \\
\hline ApF (8078 titik/points) and TfP (6671 titik/points) & 19,168 \\
\hline ApF2dpf (3502 titik/points) and TfM (998 titik/points) & 19,211 \\
\hline TfM (998 titik/ points) and ApF (8078 titik/points) & 19,221 \\
\hline TfV2m (1 524 titik/points) and RS (899 titik/points) & 19,365 \\
\hline TfB (3793 titik/points) and TfV2m (1 524 titik/points) & 19,490 \\
\hline TfV2m (1524 titik/points) and TfM (998 titik/points) & 19,540 \\
\hline TfV1 (9511 titik/points) and ApF (8078 titik/points) & 19,609 \\
\hline ApS (1422 titik/ points) and TfV2m (1 524 titik/ points) & 19,719 \\
\hline TfM (998 titik/points) and TfP (6671 titik/points) & 19,769 \\
\hline TfVI (9511 titik/points) and TfM (998 titik/points) & 19,808 \\
\hline TfV1 (9511 titik/points) and RS (899 titik/points) & 19,813 \\
\hline ApF2dpf (3502 titik/ points) and ApF (8078 titik/points) & 19,888 \\
\hline ApS (1 422 titik/points) and TfM (998 titik/points) & 19,910 \\
\hline TfB (3793 titik/points) and RS (899 titik/points) & 19,936 \\
\hline TfM (998 titik/points) and RS (899 titik/points) & 19,938 \\
\hline ApF2dpf (3502 titik/points) and TfV2m (1 524 titik/points) & 19,944 \\
\hline ApS (1 422 titik/points) and ApF (8078 titik/points) & 19,950 \\
\hline TfVI (9511 titik/points) and TfP (6671 titik/points) & 19,962 \\
\hline ApS (1 422 titik/points) and RS (899 titik/points) & 19,969 \\
\hline TfB (3793 titik/points) and TfP (6671 titik/points) & 19,976 \\
\hline ApV (2236 titik/points) and TfV2m (1 524 titik/points ) & 19,984 \\
\hline ApF2dpf (3502 titik/points) and RS (899 titik/points) & 19,984 \\
\hline TfB (3793 titik/points) and ApV (2236 titik/points) & 19,995 \\
\hline ApF2dpf (3502 titik/points) and TfP (6671 titik/points) & 19,996 \\
\hline ApS (1422 titik/points) and TfP (6671 titik/points) & 19,996 \\
\hline ApF2dpf (3502 titik/points) and ApV (2236 titik/points) & 19,996 \\
\hline ApV (2236 titik/points) and RS (899 titik/points) & 19,997 \\
\hline ApV (2236 titik/points) and ApF (8078 titik/points) & 19,999 \\
\hline ApV (2236 titik/points) and TfP (6671 titik/points) & 20,000 \\
\hline TfP (6671 titik/ points) and TfM (998 titik/points) & 20,000 \\
\hline
\end{tabular}

